Article

\title{
Exploring the Impact of Individual Characteristics Associated with Government Officials on the Severity of Real Estate Corruption
}

\author{
Hongxia Zhang ${ }^{1}{ }^{(0)}$, Yan Song ${ }^{2,3, *}$, Chaosu $\mathrm{Li}^{3, *}$, Qi Liu ${ }^{4}$, Huatai Cui ${ }^{5}$, Chen Zeng ${ }^{3,6,7}$, \\ Zhongcheng Wang ${ }^{1}$, Qian Zhang ${ }^{1}$, Yanan $\mathrm{Li}^{8}$ and Yiling Rong ${ }^{9}$ \\ 1 Department of Management, Hubei University of Education, Wuhan 430205, China; \\ zhanghongxia@hue.edu.cn (H.Z.); wangzhongcheng@hue.edu.cn (Z.W.); zhangqian@hue.edu.cn (Q.Z.) \\ 2 Department of City Planning, Shenzhen University, Shenzhen 518060, China \\ 3 Department of City and Regional Planning, University of North Carolina at Chapel Hill, Chapel Hill, \\ NC 27599, USA; lunarzeng@whu.edu.cn \\ 4 College of Public Administration, Huazhong University of Science and Technology, Wuhan 430074, China; \\ liuq2538@hust.edu.cn \\ 5 School of Economy, Renmin University of China, Beijing 100872, China; 2016000063@ruc.edu.cn \\ 6 Department of Land Management, Huazhong Agricultural University, Wuhan 430070, China \\ 7 Institute of Geographical Sciences and Natural Resources Research, Chinese Academy of Sciences, \\ Beijing 100101, China \\ 8 College of Management, Wuhan Institute of Technology, Wuhan 430205, China; lyn@wit.edu.cn \\ 9 Changzhou Urban Planning Compilation and Research Centre, Changzhou 231002, China; jzq@cczu.edu.cn \\ * Correspondence: ys@email.unc.edu (Y.S.); chaosuli@live.unc.edu (C.L.); Tel.: +1-919-962-4761 (Y.S.); \\ $+1-919-813-8355$ (C.L.)
}

Received: 8 May 2019; Accepted: 11 June 2019; Published: 17 June 2019

\begin{abstract}
In China, corruption by government officials in the field of real estate has increased at an unprecedented pace, which poses a huge threat to social sustainability. To date, scholars have primarily focused on the macroscopic determinant factors of corruption such as state intervention and economic competition; however, much less is known about the microscopic determinant factor of corruption. In this study, we use an analytical model to evaluate how individual characteristics of government officials involved in corruption cases influence and predict the scale of corruption in these cases. Based on data collected from 135 cases, the results show that age is not a key factor that affects the severity of real estate corruption; however, characteristics associated with amounts of power and levels of involvement in corruption significantly affect the severity of real estate corruption. Therefore, we propose the following countermeasures: (1) take into account the micro determinants of real estate corruption, (2) focus supervision on officials in charge of departments, key position managers, and top leaders, (3) reform the governance of each phase of real estate development and governmental involvement, and (4) enhance auditing during officials' tenures and limit the possibility of promoting officials who have participated in corruption.
\end{abstract}

Keywords: urban governance; corruption; social sustainability; China

\section{Introduction}

China's real estate market emerged in the late 1980s and had a rapid development during the 1990s. In the long run, real estate becomes one of the critical components of the pillar industries of China, although till now, it is not yet a mature market environment. China's real estate market has been supported by a relatively stable political environment and speedy economic growth; the growth of the 
real estate market has, in turn, promoted the continued growth of the economy and has strengthened political stability ("Stability" ('weihu wending' in Chinese), is a highly political terminology, which stems from the top-down political structure in China. "Political stability" indicates a predictable political environment with little social unrest, which often times have positive influences on economic growth) [1]. Estimates indicate that gross investment in China increased by $23.7 \%$ in 16 years (from $¥ 498.405$ billion in 2000 to $¥ 9597.885$ billion in 2015), contributing $4.97-13.93 \%$ toward GDP during this period (Figure 1). Chinese real estate investment approximates $15.14-17.08 \%$ of fixed-asset investment. The significant expansion of scope in the real estate market lied in that real estate is a special asset on behalf of both a consumption and investment good [2]. Thus, the demand for real estate, especially housing, continues to augment over time if China's economic growth remains at a high speed.

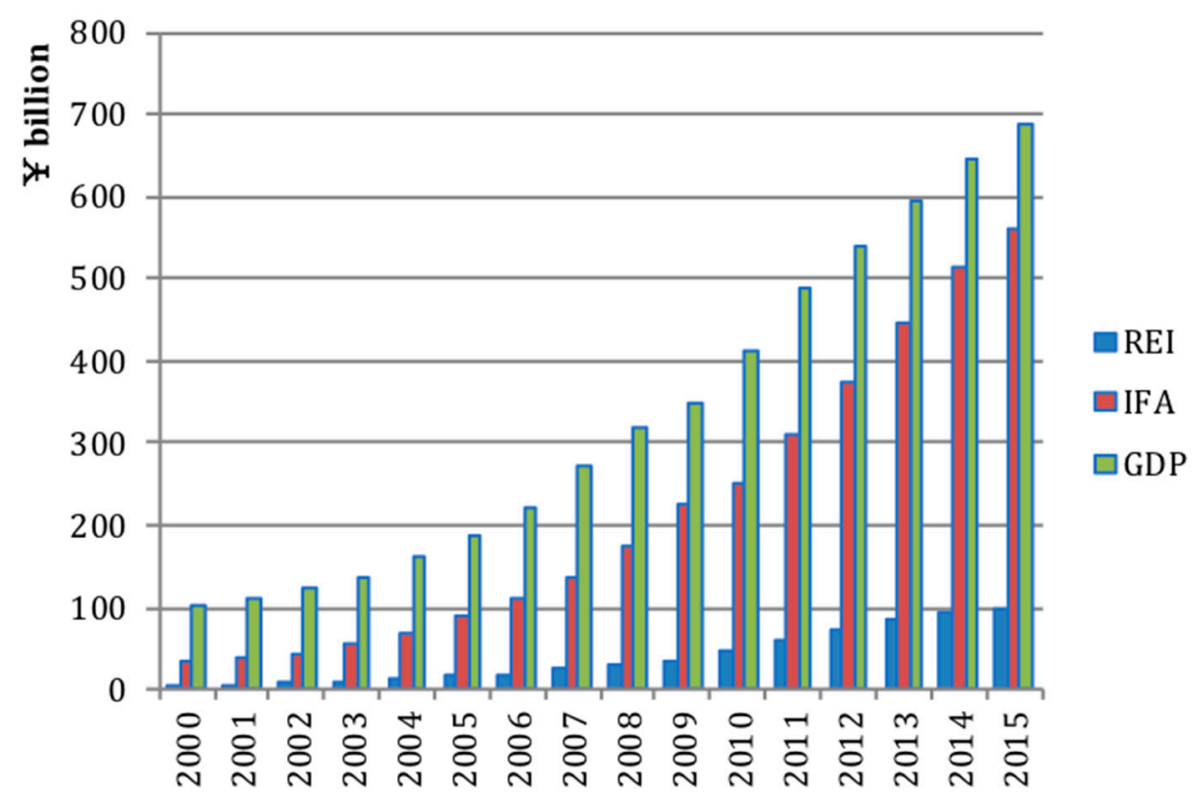

Figure 1. Real estate investment, gross investment in fixed assets, and GDP in China from 2000 to 2015. Source: National Bureau of Statistics of China.

However, corruption is endemic in the industry of Chinese real estate, and the quantity of major corruption cases has gone steadily up over the past several decades. According to the report of Legal Evening news [3], there were 12 cases related to real estate corruption in 2008, accounting for $31.5 \%$ of all cases. These cases involved $¥ 340$ million in corrupt activities. Between 2009 and 2010, there were 30 corruption cases that related to land acquisition and construction. These cases involved startling amount of money, which totaled $¥ 60$ million, with the minimum case involving $¥ 580,000$ and the average case exceeding $¥ 8.7$ million. A rough estimate indicates that developers utilized $20 \%$ of the housing sales to bribe officials ( $¥ 8.26$ trillion), and approximately $10 \%$ of China's GDP was lost to real estate corruption [4].

In recent years, real estate corruption has caused great concern to both the media and the public. Cases related to real estate corruption now appear with a high frequency, with some officials being caught shortly after a project has launched. The growth in extravagant profits for developers and the increase in corrupt officials are closely related, as government officials hold significant authority in the real estate development process. Therefore, real estate is a field that has a high prevalence of corruption. After the 18th National Congress of the Communist Party of China (NCCPC), the new leadership of the Central Committee identified cracking down on corruption as the hot issue for reform and disseminated new thoughts, ideas, and requirements of good governance in the anti-corruption battle. President $\mathrm{Xi}$ has noted the importance of standing firm in the face of increasingly serious corruption. The Commission for Central Discipline Inspection (CCDI) completed its nationwide investigation into corruption (Figure 2) and found instances of corruption in 28 provinces. On 16 July 2014, when 
the CCDI began its second round of investigations into corruption, Wang Qishan, a member of the Standing Committee of the Political Bureau of the CPC Central Committee and the lead of the Central Inspection Group, emphasized the need to oversee fields related to mineral resources, land leasing, real estate development, engineering, public funds, and special fund management. These events indicate that the Chinese government has increased its emphasis on eliminating real estate corruption and has accelerated institution-building to deter corrupt officials.

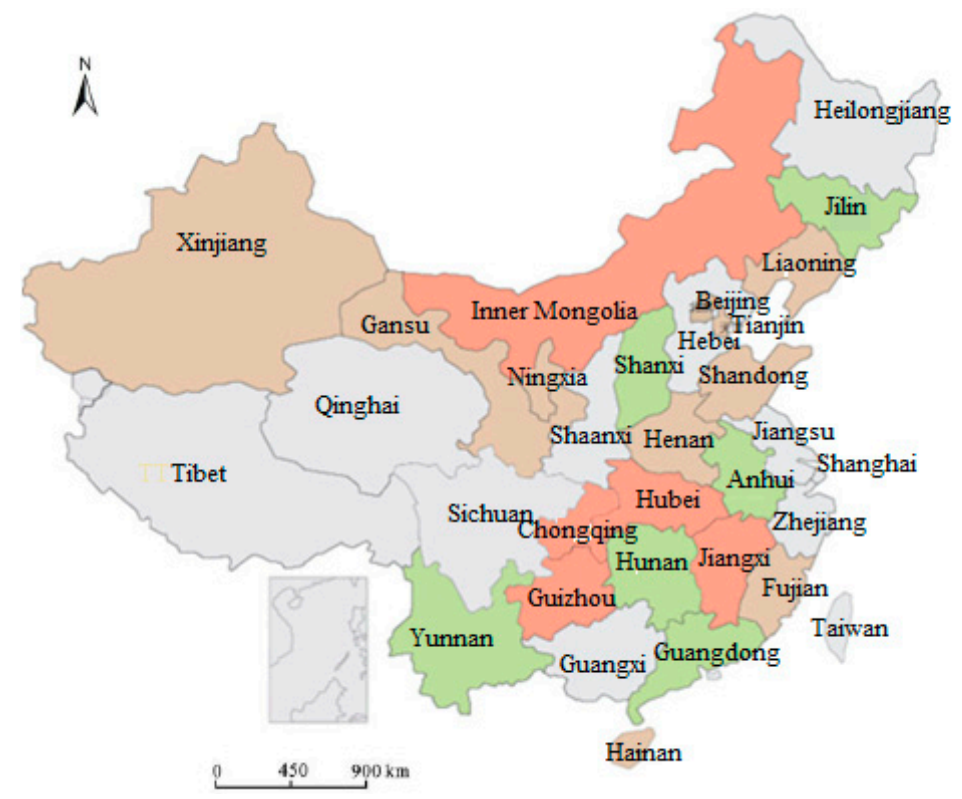

Patrol area of the 1st round in 2013

Patrol area of the 2 nd round in 2013

Patrol area of the 1 st round in 2014

Figure 2. Areas investigated by the CPC Central Commission for Discipline Inspections, by Round and Date. Source: China Economic Weekly, 5 August 2014.

Since its formation in the 1990s, China's real estate market has been a major factor in China's rapid economic growth. In accordance with the law regulating, urban land belongs to the central government. During economic reform, there has been a gradual transfer of property rights both from higher state sectors to lower government agencies and from government agencies to businesses, private groups, families, or individuals. Owing to China's special land ownership arrangement, the government wields immense power in this transfer process [5]. This reassignment of property rights provided opportunities for corrupt government officials to seek bribes because these officials have the right to determine who controls property, who shares land-related income, and who assigns property ownership.

Due to reforms in the real estate system discussed above, local governments in practice control all allocations of available land for development, and the process of land allocation is deemed to be a main venue for corruption [6]. In 1988, the government began offering long-term leases of urban land, which is called land-use rights. Developers have to pay the lease fee in full at the start of the lease period; these lease fees constitute a major source of revenue for local governments. Real estate development occurs in many phases, providing multiple points for government officials to extract bribes. There is insufficient supervision and restrictions on the power held by local officials in key positions that oversee project planning, financing, and approval, allowing for corrupt officials to leverage their power for personal gains.

Since 2007, at least 20 senior government officials have been linked to real estate corruption; these officials include the former deputy mayor of Hangzhou, the former municipal party secretary of Qingdao, the former municipal party secretary of Shanghai, the former deputy governor of Anhui province, the former deputy mayor of Beijing, and the former head of the Land Resources Bureau of Liaoning Fushun city. These officials all used their positions to benefit others and accept bribes during land transfers, project contracting, engineering and construction, urban planning, and municipal 
construction. Undoubtedly, corruption in real estate has become a grave social issue and one of the major challenges to effective governance in China. Although the CPC and the government have taken actions to restrain corruption committed by government officials, the bribery scandals appear to be prevalent in the field of real estate [4].

As China's economic reforms move forward, real estate corruption becomes more serious with huge amount of money and senior officials involved, which poses a huge threat to social sustainability (Social sustainability is a broad term in the current literature, which incorporates dimensions of social equity, social cohesion, diversity, democracy and governance, etc.) since real estate corruption could lead to weak institutions and injustice and stifle sustained economic growth, especially in the Chinese context. Therefore, it is necessary to explore the factors that shape real estate corruption. In view of the related studies, two questions are addressed in the present study. First, what are common characteristics of corrupt government officials? Second, how do these characteristics affect the severity of corruption, particularly the amount of money involved on a case by case basis? The primary purpose of this research is to identify the impact of individual characteristics on the severity of real estate corruption. To do this, we analyze data related to corruption collected from legal indictments of corrupt officials, prosecution records, and media articles and conduct a quantitative study on individual characteristics of corrupt government officials. Thus, the nature and the factors that influence real estate corruption can be better understood. This created an opportunity to recognize and study anti-corruption, an issue closely related to social sustainability, yet left largely unexplored in literature. In response to this issue, the evidence we present will be useful for researchers, policymakers, and anti-corruption professionals who have a mind to improve the measures of China's anti-corruption and promote long-term social sustainability.

The following are the main contents of the research. Section 2 reviews some relative literature. Section 3 discusses data and variables, and Section 4 conducts descriptive statistics. Section 5 introduces the model used to calculate the impact of individual characteristics on the severity of real estate corruption. Section 6 presents the findings. Section 7 discusses our conclusions and the implications of this study on policy.

\section{Literature Review}

Corruption goes off the normal duties of a public role, entangles with pecuniary or status gains, and breaches the official ethics of public service [7,8]. Many scholars, including Myrdal [9], Rosenn [10], Tanzi [11] and La Porta et al. [12], hypothesized that bureaucrats intentionally make trouble for market transaction, often referred to as red tape, to extract bribes. Additionally, Bertrand et al. [13] argued that such profits are transited through intermediaries. However, only a limited amount of research has examined corruption in real estate. Dodson et al. [14] studied corruption during land development in Australia and found that this phenomenon is common. Murray and Frijters [15] showed that well-connected landowners benefit most from rezoning, and that billions of dollars of economic rent are regularly transmitted from the public to these landowners who have close relationship with government officials. Koumpias et al. [16] analyzed corruption in zoning in Greece and Spain, the result of this study implicated that most of corruption scandals correlate with city development and construction projects. Corruption has recently been explored in the literature regrading sustainability in a sense that it could potentially affect the three dimensions of sustainable development. Some existing literature has discussed real estate corruption in China, focusing on the overall phenomenon of corruption, factors that lead to corruption and countermeasures to combat corruption. For example, Zhang $[4,17]$ and $\mathrm{Mu}$ [18] considered real estate to be high prevalence area of corruption, which is reflected as power-for-money deals. Liu [19], Tan [20] and Zhang [21,22] thought that the lack of free market and the high concentration of official power are the mainspring of corruption. Then, Zheng [23] and Tan [24] proposed to create a well-functioning market and an effective official accountability to prevent government officials from abuse power for personal gains. 
The factors that lead to corruption are both numerous and complex. Some scholars argued that individuals would engage in corruption when an opportunity to embezzle public funds coincided with their discretionary power [25-28]. Aidt [29] further found that corruption was very likely to occur when individuals hold power and this power can be abused under given conditions. Denin [30] demonstrated that the collusion between high-rank officials and developers leads to greater amounts of corruption. Le et al. [31] found that corruption with large sums of money was closely related to officials' leadership and rank. Also, some research showed that level of position increases corruption [32-35], whereas Ren and $\mathrm{Du}$ [36] and Kotera et al. [37] concluded that positions with centralized authority (as opposed to a system where power is delegated to multiple people) was the key factor that influences corruption with government officials. Liu [19] indicated that the lack of a free land transaction market creates space for government officials to seek rent and private gain through power. Deng et al. [38] suggested that officials might commit corrupt crimes after the age of 59 because it was probable for them to use their power for personal proceeds before the official retirement age. Wang et al. [3] made a bivariate analysis of the gender, age, rank, education, as well as amount of money involved in cases for officials convicted of corruption, revealed that the power levels and behavior features have obvious impact on corruption amount. Bernardino et al. [39] analyze the determinants of urban political corruption in local governments found that higher salaries and more transparency are connected with less corruption. Daniel et al. [40] further recommended that anti-corruption investigation is more effective when top officials are targeted. Although studies are gradually incorporating officials' characteristics related to corruption [41-47], case study analyses on corrupt officials remain very limited.

The topic of corruption has increasingly attracted the attention of academic scholars, yet there is still a lack of literature on how individual characteristics associated with government officials affect their corrupt behavior. Therefore, our goal is to analyze these characteristics in an attempt to provide explanations for corruption; we hope that this will assist in combating corruption in real estate. In this study, based on factual analysis and quantitative reasoning, we attempt to identify individual characteristics of government officials that have been prosecuted for corruption to explain the factors that influence real estate corruption. Furthermore, we call for values-based controls over government officials. As Bourgon [48] noted, public administrations required not only sturdy institutions and legislation but also accountability, citizenship, and government credibility.

\section{Data and Variables}

Performing quantitative studies on corruption is challenging due to inaccessibility of clear, reliable, and consistent data. We obtained data for this study through content analyses of news articles and press releases, which analyze term frequency of the text content and extracts the most frequent meaningful words that can be used to describe real estate corruption. The main key words used for collecting data are 'real estate corruption', 'corrupt officials', 'professional misconduct', 'public power corruption', 'embezzle money', 'guilty of corruption', 'bribe-taking of civil servants', 'unlawful act of real estate management' and 'rent-seeking in real estate'. These news articles and press releases cover cases that were investigated and prosecuted from 2013 to 2015, including 127 cases disclosed by the supervisory department of the CCDI, 55 cases disclosed by the leadership team in the central government on controlling prominent issues in the field of engineering and construction, 68 cases disclosed by Housing Policy Online and the Procuratorial Daily, and more than 100 cases disclosed by procuratorates, discipline commissions, and supervisory departments at all levels. After evaluating the completeness of narration and representativeness of content available for each case, we finally selected 135 cases to serve as the basis for this study. Information on these cases was available because the occurrence of an unexpected event; additionally, information available for these cases is relatively complete because they attracted considerable attention from the general public. For reasons discussed in previous sections of this paper, we collected details including the age, power, and level of involvement for government officials in these corruption cases (Table 1). The measurement scale of the involvement indicates the frequency of government officials' involvement to corruption: from 
$1=$ seldom to $5=$ quite often. Based on the data drawn from content analysis, we use such criteria to measure the frequency as $1=$ seldom ( $0-1$ time), less $=2$ ( 2 times), occasionally $=3$ ( 3 times), often $=4$ ( 4 times), quite often $=$ (above 4 times).

Table 1. Variables in the econometric model.

\begin{tabular}{|c|c|c|}
\hline & Name of Variable & Definition of Variable \\
\hline \multirow[b]{2}{*}{$\begin{array}{l}\text { Amount of Money Involved in } \\
\text { Corruption Cases }\end{array}$} & Sum & Amount of money involved in a corruption case \\
\hline & Sum2 & $\begin{array}{l}\text { Amount of money involved in corruption cases, } \\
\text { as divided into five levels: below } 500,000=1, \\
510,000-1 \text { million }=2,1.01 \text { million }-5 \text { million }=3, \\
5.01 \text { million-10 million }=4 \text {, above } 10 \text { million }=5\end{array}$ \\
\hline \multirow[b]{2}{*}{ Age } & Age & $\begin{array}{l}\text { Age of the government official at the time the } \\
\text { corrupt act was committed }\end{array}$ \\
\hline & Age2 & $\begin{array}{l}\text { Age of the government official at the time the } \\
\text { corrupt act was committed, as divided into five } \\
\text { levels: below } 45=1,46-50=2,51-55=3 \text {, } \\
56-60=4 \text {, above } 60=5\end{array}$ \\
\hline \multirow{3}{*}{ Power, Location\& Time } & Tiers & $\begin{array}{l}\text { City where corruption took place occurred, as } \\
\text { divided into five levels: fifth-tier city }=1 \text {, } \\
\text { fourth-tier city }=2 \text {, third-tier city }=3 \text {, second-tier } \\
\text { city }=4 \text {, first-tier city }=5\end{array}$ \\
\hline & Location & $\begin{array}{l}\text { The five administrative levels of the } \\
\text { governmental unit for the government official } \\
\text { that participated in corruption: township }=1 \text {, } \\
\text { county }=2 \text {, municipality }=3 \text {, province }=4 \text {, } \\
\text { central ministries }=5\end{array}$ \\
\hline & Position & $\begin{array}{l}\text { The five position levels within the governmental } \\
\text { unit for the government official that participated } \\
\text { in corruption: clerk }=1 \text {, department head }=2 \text {, } \\
\text { director }=3 \text {, deputy }=4 \text {, top leader }=5\end{array}$ \\
\hline \multirow{7}{*}{ Level of Involvement } & Year & $\begin{array}{l}\text { The number of years between when the corrupt } \\
\text { act was committed to when the act was } \\
\text { investigated and prosecuted. }\end{array}$ \\
\hline & Year2 & $\begin{array}{l}\text { The number of years between when the corrupt } \\
\text { act was committed to when the act was } \\
\text { investigated and prosecuted, as divided into the } \\
\text { following five levels: } 1-3 \text { years }=1,4-5 \text { years }=2 \text {, } \\
6-8 \text { years }=3,9-10 \text { years }=4 \text {, above } 10 \text { years }=5\end{array}$ \\
\hline & Land & $\begin{array}{l}\text { The five levels of involvement in the land transfer } \\
\text { process: seldom involve }=1 \text {, less involve }=2 \text {, } \\
\text { occasionally involve }=3 \text {, often involve }=4 \text {, quite } \\
\text { often involve }=5\end{array}$ \\
\hline & Project & $\begin{array}{l}\text { The five levels of involvement in project } \\
\text { contracting: the same as above }\end{array}$ \\
\hline & Plan & $\begin{array}{l}\text { The five levels of involvement in plan design: } \\
\text { the same as above }\end{array}$ \\
\hline & Construction & $\begin{array}{l}\text { The five levels of involvement in engineering } \\
\text { construction: the same as above }\end{array}$ \\
\hline & Sale & $\begin{array}{l}\text { The five levels of involvement in real estate sales: } \\
\text { the same as above }\end{array}$ \\
\hline
\end{tabular}

Notes: Tiers designations are based on the Chinese city grading list published by CBN weekly on 25 April 2016. Position: designations are based on levels described in the Civil Servant Law of the People's Republic of China. Level of involvement refers to Document No. 22 (2010). 
We have included 12 explanatory variables in this study. Additionally, there are two dependent variables that represent the total amount of money involved in each case (Sum and Sum2). We have included discrete variables for the age of a government official at the time when corrupt acts were committed (Age), the number of years between corrupt acts being committed and when they were prosecuted (Year), and for the total financial amount associated with each case of corruption (Sum); all other variables are categorical variables, because their metrics all have definite orders or levels. The values of these categorical variables range from 1 to 5 , with 1 referring to the lowest level and 5 referring to the highest level.

Age is captured both as a discrete variable (Age, for the age of the official) and as a categorical variable (Age2). Age2 is divided into five levels: below 45, 46-50, 51-55, 56-60, and above 60.

Tiers reflect the economic development of the area where the corruption occurred. Cities are divided into five levels based on the CBN weekly Magazine's April 2016 rankings. The lowest ranking represents fifth-tier cities, and the highest ranking represents first-tier cities.

Location reflects the level of the governmental unit where the corruption took place. Governments have been divided into five levels for this study: townships, counties, municipalities, provinces, and ministries within the central government.

Position is measured by the government official's status within the governmental leadership hierarchy and reflects the corrupt official's authority to issue orders and execute decisions. Data for the variable Leadership is divided into five levels: clerk, department head, director, deputy, and top leader.

Two variables are used to capture the time span between when the corrupt act occurred to when the corrupt act was investigated and prosecuted. One discrete variable represents this time in years (Year), and the other categorical variable captures its data in groups of years (Year2). The variable Year2 is divided into five levels: $1-3$ years, $4-5$ years, $6-8$ years, 9-10 years, and above 10 years.

The dataset also includes variables to indicate when the corrupt acts occurred during the real estate development process. Variables that measure when corruption occurred represent land transfers (Land), plan design (Plan), project contracting (Project), construction (Construction) and real estate sales (Sale). Values for this variable represent the level of involvement by corrupt officials. These five levels include 'seldom involve', 'less involve', 'occasionally involve', 'often involve', and 'quite often involve', reflecting that the scale is 'weak- to strong'.

The two dependent variables, Sum and Sum by category (Sum2), reflect the amount of money involved in corruption cases. The variable Sum is a discrete variable and represents the actual value of the money related to corrupt officials. For Sum2, we divided the amounts of money associated with each case into five levels reflecting the severity of real estate corruption. The levels include 'slightly severe' (below $¥ 500,000)$, 'moderately severe’ ( $¥ 510,000-¥ 1$ million), 'significantly severe' (¥1.01 million- $¥ 5$ million), 'quite severe' (¥5.01 million- $¥ 10$ million), and 'fiercely severe' above (¥10 million).

\section{Descriptive Statistics}

Table 2 contains descriptions of the 12 explanatory variables used in our analysis, and Table 3 shows a breakdown of cases as they relate to different characteristics associated with government officials and the average value of categorized money (Sum2) involved. Table 4 shows the percentage of cases associated with the stage and level of involvement for each corruption case and the average amounts of money involved in these cases.

From Table 3, it can be seen that the average value of Sum2 is relatively high in second-tier (3.56) and third-tier cities (3.58). A majority of corruption cases involve government officials at the municipal $(45.6 \%)$ and provincial levels (26.8\%); this is likely because these levels of government manage major real estate projects. A majority of cases relate to officials at "clerk" (50.2\%) and "department head" $(32.6 \%)$ levels (i.e., bureau level or county levels) who appear to be inclined to intervene and take specific responsibility for real estate operation and management and thus seek benefits that constitute corruption. 
Table 2. Descriptive statistics about the explanatory variables.

\begin{tabular}{ccccccc}
\hline & Variable & $\begin{array}{c}\text { Average } \\
\text { Value }\end{array}$ & $\begin{array}{c}\text { Standard } \\
\text { Deviation }\end{array}$ & $\begin{array}{c}\text { Minimum } \\
\text { Value }\end{array}$ & $\begin{array}{c}\text { Maximum } \\
\text { Value }\end{array}$ & T-Verification \\
\hline \multirow{2}{*}{ Age } & Age & 50.81 & 6.429 & 37 & 62 & $95.595^{* * *}$ \\
& Age2 & 2.51 & 1.218 & 1 & 5 & $27.232^{* * *}$ \\
\hline \multirow{2}{*}{$\begin{array}{c}\text { Location, Position, } \\
\text { and latent period }\end{array}$} & Liers & 3.29 & 1.372 & 1 & 5 & $28.109^{* * *}$ \\
& Location & 3.37 & 0.876 & 2 & 5 & $46.916^{* * *}$ \\
& Position & 1.95 & 1.301 & 1 & 5 & $20.703^{* * *}$ \\
\hline \multirow{2}{*}{ Involvement } & Year & 8.02 & 3.455 & 1 & 20 & $40.507^{* * *}$ \\
behavior & Year2 & 3.43 & 1.087 & 1 & 5 & $28.164^{* * *}$ \\
& Land & 2.85 & 1.933 & 1 & 5 & $19.756^{* * *}$ \\
& Project & 1.71 & 1.295 & 1 & 5 & $17.983^{* * *}$ \\
& Plan & 1.86 & 1.487 & 1 & 5 & $15.305^{* * *}$ \\
& Construction & 3.49 & 1.686 & 1 & 5 & $22.252^{* * *}$ \\
& Sale & 1.93 & 1.654 & 1 & 5 & $18.431^{* * *}$ \\
\hline
\end{tabular}

Note: ${ }^{* * *}$ indicates significance at $1 \%$.

Table 3. Detailed statistics on the percentage of cases and mean values by categorization level of the variables associated with Tiers-Location and Position-related characteristics.

\begin{tabular}{ccccccc}
\hline $\begin{array}{c}\text { Categorization } \\
\text { Level of } \\
\text { Variables }\end{array}$ & \multicolumn{2}{c}{ Tiers } & \multicolumn{2}{c}{ Location } & \multicolumn{2}{c}{ Position } \\
\cline { 2 - 6 } & \% of Cases & $\begin{array}{c}\text { Sum2 Average } \\
\text { Value }\end{array}$ & \% of Cases & $\begin{array}{c}\text { Sum2 Average } \\
\text { Value }\end{array}$ & \% of Cases & $\begin{array}{c}\text { Sum2 Average } \\
\text { Value }\end{array}$ \\
\hline Level 1 & 12.7 & 3.47 & 1.2 & 3.35 & 50.2 & 3.40 \\
Level 2 & 20.3 & 3.45 & 13.3 & 3.71 & 32.6 & 3.50 \\
Level 3 & 21.1 & 3.58 & 45.6 & 3.34 & 1.7 & 3.95 \\
Level 4 & 22.3 & 3.56 & 26.8 & 3.15 & 3.8 & 3.28 \\
Level 5 & 23.6 & 3.28 & 13.1 & 3.56 & 10.7 & 3.58 \\
Overall & 100 & - & 100 & - & 100 & - \\
\hline
\end{tabular}

Table 4. Detailed statistics on the percentage of cases and mean values by categorization level of the variables during different phases in the real estate development process.

\begin{tabular}{|c|c|c|c|c|c|c|c|c|c|c|}
\hline $\begin{array}{c}\text { Categorization } \\
\text { Level of } \\
\text { Variables }\end{array}$ & \multicolumn{2}{|c|}{ Land } & \multicolumn{2}{|c|}{ Project } & \multicolumn{2}{|c|}{ Plan } & \multicolumn{2}{|c|}{ Construction } & \multicolumn{2}{|c|}{ Sale } \\
\hline Level 1 & 2.40 & 3.13 & 3.20 & 3.12 & 1.30 & 2.62 & 4.10 & 2.55 & 2.80 & 2.50 \\
\hline Level 2 & 2.61 & 3.22 & 4.20 & 3.15 & 1.60 & 2.65 & 4.80 & 3.52 & 4.10 & 2.76 \\
\hline Level 3 & 3.50 & 4.04 & 24.40 & 4.45 & 4.10 & 3.81 & 8.00 & 3.68 & 10.2 & 3.30 \\
\hline Overall & 100 & - & 100 & - & 100 & - & 100 & - & 100 & - \\
\hline
\end{tabular}

From Table 2, it can be seen that officials commit corrupt activities mainly during the land transfer phase (2.85) and the construction phase (3.49), and from Table 4, we find that when participating in corruption, officials often serve in "quite often involve" roles.

Among the 135 cases reviewed in this study, the ages of corrupt officials ranged from 37 to 62 years old, with an average age of 50.81 years old. As shown in Figure 3, there are clusters of ages for officials involved in corruption between the 46-50 and 55-60 age ranges. According to the system of public service of China, the normal promotion of civil servant from a clerk to a leading role of the department at least takes 25 years, and provisional regulations on civil servants regulate that male staffs retire at age 60 and female staffs retire at age 55. Therefore, these two age ranges can be described in different ways: the first range represents the "promotion age" of the official, referring to the best period for career; the second range represents the "pre-retirement age" of the officials, referring to the period shortly before retirement. Corruption during this period prior to retirement is referred to as the "59-year old 
phenomenon", and it reflects officials attempting to secure personal benefits prior to retiring. Therefore, it appears that age has an impact on criminal behavior [49]. As shown in Figure 4, the longest period between corrupt acts and being prosecuted for corrupt acts is 20 years, with the average delay being 8.02 years. The amount of money involved in 135 cases ranged from hundreds of thousand yuan to hundreds of million yuan, with the average per case being $¥ 6.997$ million.

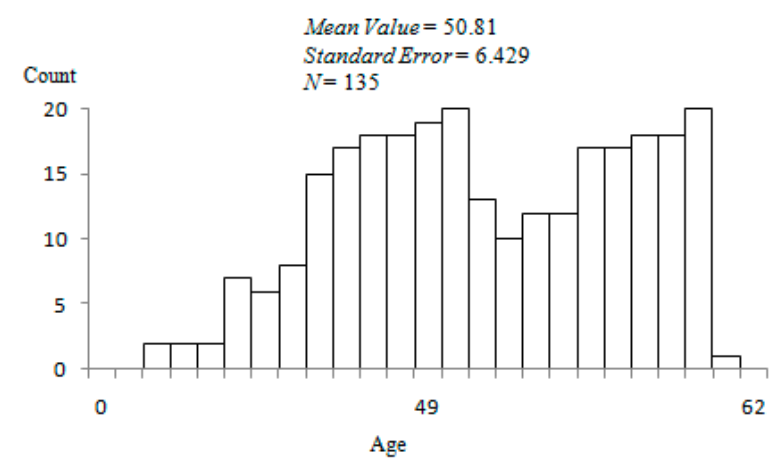

Figure 3. Distribution of corruption cases by age of government official.

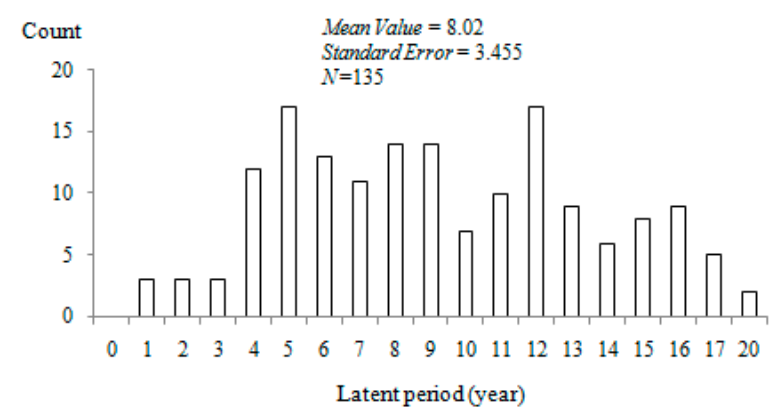

Figure 4. Distribution of corruption cases by gap between when corruption was committed to when it was discovered.

\section{Model}

For this study, we use both continuous and ordinal explanatory variables to explain the impact factors of real estate corruption. Therefore, we have utilized two models, multiple regressions, and an ordered probit regression for mutual validation to ensure the robustness of our results. Firstly, a multiple regression model can combine continuous predictors and categorical predictors with their interaction terms, to synchronously estimate the mixed effect of those parameters on the outcome. Secondly, the ordered probit model has broader applicability to evaluate the ordinal nature of a target variable, besides discerning statistically significant relationships between independent variables and a dependent variable, it also identifies unequal deviations between ordinal classes in the dependent variable [50]. Additionally, it also requires smaller samples when compared to unordered response models [51].

We define the basic model of the multiple regressions as follows:

$$
\text { LnSum }=\beta_{1}+\beta_{2} x_{i}+\varepsilon,
$$

where LnSum denotes the natural logarithmic operator of the severity of real estate corruption, $x_{i}$ is the explanatory variable which includes characteristics like age, power, and involvement in corruption, and $\varepsilon$ represents random error.

To resolve potential problems associated with collinearity between explanatory variables, we first used a ridge regression to analyze and discern the function and relationship between paired explanatory variables. Next, we used a robust stepwise regression to examine the collinearity of variables through the variance inflation factor (VIF) using the characteristics of Age and Power, involvement in different 
phases of the real estate process, and the delay period between corrupt acts being committed and being caught as the four groups of test variables. We found that Land and Year2, have the statistically significant impact on LnSum ( $p<0.01$ ), and $R^{2}$ of the multiple regression model is relatively small (Table 5). We then utilized an ordered probit model to identify the functional mechanisms for each individual characteristic variable on real estate corruption.

Table 5. Estimation of multiple regression.

\begin{tabular}{cccc}
\hline & Coefficient & t-Statistic & $p$ Value \\
\hline Age & 0.001 & 3.763 & 0.0825 \\
Age2 & 0.006 & 3.872 & 0.0656 \\
Tiers & -0.054 & -4.255 & 0.0513 \\
Location & -0.032 & -4.168 & 0.0445 \\
Position & 0.011 & 3.823 & 0.0393 \\
Year & 0.022 & 4.191 & 0.0427 \\
Year2 & 0.098 & 5.007 & 0.0051 \\
Land & 1.783 & 5.125 & 0.0012 \\
Project & -0.089 & -3.346 & 0.0767 \\
Plan & 0.017 & 2.599 & 0.0408 \\
Construction & 0.012 & 2.712 & 0.0394 \\
Sale & -0.033 & -2.894 & 0.0442 \\
$R^{2}$ & 0.226 & \multicolumn{2}{c}{0.227} \\
Adj $R^{2}$ & 0.225 & \multicolumn{2}{c}{0.226} \\
F-test & 110.089 & \multicolumn{2}{c}{106.313} \\
$N$ & 135 & \multicolumn{2}{c}{135} \\
\hline \multicolumn{4}{c}{}
\end{tabular}

A multivariate probit model of dependent variables or alternatives can be generally expressed as [52]:

$$
y_{i}^{*}=\beta_{i} x_{i}+e_{i}, i=1, \ldots, n
$$

defines an unobserved variable (level of corruption severity) representing the latent utility (or propensity) for considering alternative,

$x_{i}$ is a vector of observed characteristics determining choice alternative $i$, contains the variable that is assumed to affect the severity of corruption.

$\beta_{i}$ represents a vector of unknown coefficients to be estimated, and

$e_{i}$ represents a vector of error terms that are normally distributed with zero mean and constant variance.

$i$ represents the $i$ th case.

The variance covariance matrix of the error term is given as follows:

$$
\sum=\left[\begin{array}{ccc}
1 & \cdots & \rho 1 n \\
\vdots & \ddots & \vdots \\
\rho n 1 & \cdots & \rho n n
\end{array}\right]
$$

where $\rho$ is a measure of the correlation among the latent utilities.

In the probit model, it is assumed that $y_{i}^{*}$ is related to the observable ordinal variable $y_{i}$ as follows:

$$
y_{i}=\left\{\begin{array}{l}
1, \text { if } y_{i}^{*} \leq c_{1} \\
2, \text { if } c_{1}<y_{i}^{*} \leq c_{2} \\
3, \text { if } c_{2}<y_{i}^{*} \leq c_{3} \\
4, \text { if } c_{3}<y_{i}^{*} \leq c_{4} \\
5, \text { if } c_{4}<y_{i}^{*} \leq c_{5}
\end{array}\right.
$$


$c_{1,2,3,4,5}$ indicates the thresholds or cut-points to be projected for each level. As explained in [53], the equation for the probabilities of $y_{i}=1,2,3,4,5$ will be:

$$
P\left(y_{i}^{*}=j\right)=F\left(c_{j}-x_{i} \beta_{i}\right)-F\left(c_{j-1}-x_{i} \beta_{i}\right)
$$

where $j$ takes a value 1 to $5, F\left(c_{j}-x_{i} \beta_{i}\right)$ and $F\left(c_{j-1}-x_{i} \beta_{i}\right)$ means the operator of cumulative distribution function for the standard normal. $c_{j}$ and $c_{j-1}$ denote the lower threshold and the upper threshold for the corruption severity scale $j$, respectively.

Estimation of these probabilities allows a better grasping of the relative of the explanatory variables. For instance, some factors may be more possible to cut down the probability of the severity of real estate corruption, while others may be more effective at increasing the severity of real estate corruption. To keep all the probabilities being positive, the threshold values must meet the restriction $c_{1}<\ldots<c_{j}<\ldots<c_{j-1}$. A positive value of $\beta_{i}$ indicates that an increase in $x_{i}$ will obviously generate the increase of the probabilities of the highest ordered corruption severity scales, and vice versa. However, it is not clear what effect a positive or negative $\beta_{i}$ will bring forth on the probabilities of the intermediate scales. Because of this, Washington et al. [54] suggest computing the marginal effects for each scale. The marginal effect or partial change which can uncover the effects of the explanatory variables on the probability of five different scales of corruption severity individually. For estimation, the corresponding marginal effect is:

$$
\frac{P\left(y_{i}^{*}=j\right)}{\partial x_{i}}=\left[F\left(c_{j}-x_{i} \beta_{i}\right) \beta-F\left(c_{j-1}-x_{i} \beta_{i}\right)\right] \beta_{i}
$$

We used STATA software to run the ordered probit regression model, and the results are listed in Table 6. Then, we calculated the predicted probability of the level of the severity of real estate corruption based on the Prvalue function of STATA software. When making such a prediction, we took the average value for non-given explanatory variables. The predicted probability estimates are shown in Table 7.

Table 6. Regression results of the ordered probit model.

\begin{tabular}{cccccc}
\hline \multicolumn{2}{c}{ Dependent Variable: Sum2 Represents the Scale of Severity of Real Estate Corruption } \\
\hline Explanatory Variable/Index Variable & Average Value & Coefficient & Standard Error & $Z$ & $p$ Value \\
\hline Age 2 & 2.51 & 0.016 & 0.079 & 0.20 & 0.795 \\
Age2 $=2$ & - & 0.559 & 0.338 & 1.70 & $0.093^{*}$ \\
Tiers & 3.29 & -0.025 & 0.065 & -0.42 & 0.688 \\
Location & 3.37 & -0.021 & 0.119 & -0.18 & 0.867 \\
Location $=3$ & - & -0.799 & 0.472 & 0.175 & $0.062^{*}$ \\
Location $=4$ & - & -0.966 & 0.475 & -2.01 & $0.035^{* *}$ \\
Position & 1.95 & 0.112 & 0.071 & 1.52 & $0.171^{*}$ \\
Year2 $=5$ & 3.43 & 0.233 & 0.092 & 2.47 & $0.015^{* *}$ \\
& - & 1.461 & 0.758 & 1.86 & $0.057^{*}$ \\
Land $=4$ & - & 2.85 & 0.937 & 3.09 & $0.004^{* *}$ \\
Land $=5$ & - & 0.678 & 0.235 & 2.69 & $0.008^{* *}$ \\
Plan & 1.86 & 0.059 & 0.061 & 1.06 & 0.271 \\
Project & 1.71 & -0.047 & 0.068 & -0.74 & 0.439 \\
Construction & 3.49 & 0.051 & 0.535 & 0.67 & 0.431 \\
Construction $=5$ & - & -1.409 & 0.688 & -2.02 & $0.045^{* *}$ \\
Sale & 1.93 & -0.015 & 0.057 & -0.23 & 0.797 \\
Sale $=5$ & - & 1.776 & 0.647 & 2.59 & $0.012^{* *}$ \\
Pseudo $R^{2}$ & 0.0487 & & Prob $>$ chi2 & & 0.0321
\end{tabular}

Note: ${ }^{*}$ and ${ }^{* *}$ stand for significance at $10 \%$ and $5 \%$, respectively; we only list the index variables with significance above $10 \%$. 
Table 7. Prediction probability of the severity scale of real estate corruption involved in a case.

\begin{tabular}{|c|c|c|c|c|c|}
\hline \multirow{2}{*}{$\begin{array}{c}\text { Explanatory } \\
\text { Variable/Index Variable }\end{array}$} & 1 & 2 & 3 & 4 & 5 \\
\hline & (Slightly Severe) & (Moderately Severe) & (Significantly Severe) & (Quite Severe) & (Fiercely Severe) \\
\hline $\begin{array}{c}\text { Reference } \\
\text { Age2 } \\
\text { Tiers }\end{array}$ & 0.06 & 0.12 & 0.41 & 0.16 & 0.25 \\
\hline Tires $=3$ & 0.05 & 0.06 & 0.37 & 0.25 & 0.26 \\
\hline $\begin{array}{l}\text { Tiers }=4 \\
\text { Location } \\
\text { Position }\end{array}$ & 0.05 & 0.05 & 0.37 & 0.26 & 0.27 \\
\hline Position $=1$ & 0.05 & 0.14 & 0.43 & 0.15 & 0.23 \\
\hline Position $=3$ & 0.04 & 0.10 & 0.40 & 0.17 & 0.29 \\
\hline Position $=4$ & 0.03 & 0.07 & 0.39 & 0.17 & 0.34 \\
\hline $\begin{array}{c}\text { Position }=5 \\
\text { Year } 2\end{array}$ & 0.03 & 0.07 & 0.34 & 0.19 & 0.37 \\
\hline Year $2=1$ & 0.07 & 0.09 & 0.42 & 0.17 & 0.26 \\
\hline Year2 $=2$ & 0.05 & 0.07 & 0.43 & 0.18 & 0.27 \\
\hline Year2 $=3$ & 0.04 & 0.06 & 0.44 & 0.18 & 0.28 \\
\hline Year2 $=4$ & 0.03 & 0.06 & 0.44 & 0.18 & 0.29 \\
\hline $\begin{array}{l}\text { Year } 2=5 \\
\text { Land }\end{array}$ & 0.03 & 0.07 & 0.35 & 0.17 & 0.38 \\
\hline Land $=4$ & 0.02 & 0.04 & 0.16 & 0.31 & 0.47 \\
\hline $\begin{array}{l}\text { Land }=5 \\
\quad \text { Plan }\end{array}$ & 0.01 & 0.02 & 0.17 & 0.32 & 0.48 \\
\hline Plan $=4$ & 0.03 & 0.11 & 0.17 & 0.32 & 0.37 \\
\hline $\begin{array}{c}\text { Plan }=5 \\
\text { Project }\end{array}$ & 0.03 & 0.08 & 0.23 & 0.25 & 0.41 \\
\hline Project $=3$ & 0.05 & 0.13 & 0.15 & 0.26 & 0.41 \\
\hline Project $=4$ & 0.04 & 0.11 & 0.15 & 0.27 & 0.43 \\
\hline $\begin{array}{l}\text { Project }=5 \\
\text { Construction }\end{array}$ & 0.02 & 0.09 & 0.16 & 0.28 & 0.45 \\
\hline Construction $=4$ & 0.06 & 0.11 & 0.16 & 0.24 & 0.43 \\
\hline $\begin{array}{c}\text { Construction }=5 \\
\text { Sale }\end{array}$ & 0.05 & 0.05 & 0.18 & 0.27 & 0.45 \\
\hline Sale $=3$ & 0.07 & 0.11 & 0.15 & 0.32 & 0.35 \\
\hline Sale $=4$ & 0.06 & 0.08 & 0.16 & 0.33 & 0.37 \\
\hline Sale $=5$ & 0.02 & 0.05 & 0.17 & 0.34 & 0.44 \\
\hline
\end{tabular}

Note: we only list the predictive value with significant change compared to the reference value.

\section{Results}

According to Tables 6 and 7, we present the following findings.

First, a change in age does not produce a significant change in the scale of severity of real estate corruption; therefore, age is not the impact factor of real estate corruption.

Second, the variables associated with power do impact the scale of severity of real estate corruption. On one side, the results indicate that second-tier and third-tier cities play an important role in the severity of real estate corruption, the prediction probability of "quite severe" and "fiercely severe" related to the former is $0.51(0.25+0.26)$; and that related to the latter is $0.53(0.26+0.27)$, they are $10 \%$ and $12 \%$ higher than the reference value of $0.41(0.16+0.25)$, respectively. On the other side, the probability that a corruption case for the top official within a governmental unit (Position =5) will lead to "fiercely severe" (0.37), which is 12 percentage points higher than the reference value (0.25), whereas the probability of "slightly severe" and "moderately severe" for the same type of governmental leader decreases from $0.18(0.06+0.12)$ to $0.10(0.03+0.07)$.

Third, the longer latent periods lead to greater severity of real estate corruption. As the length of the delay between committing and being prosecuted for corruption increases, the scale of severity of real estate corruption also increases. For example, when comparing cases with a delay period between 1 to 3 years (Year2 $=1$ ) with those of greater than 10 years (Year2 $=5$ ), we find that the probability of "slightly severe" and "moderately severe" decreases from the reference value of $0.16(0.07+0.0 .09)$ to $0.10(0.03+0.07)$, whereas the probability of "quite severe" and "fiercely severe" increases from $0.43(0.17+0.26)$ to $0.55(0.17+0.38)$. 
Fourth, the level of involvement for government officials and the probability of severity scale of real estate corruption are positively correlated; that is, the more involved an official is in corruption, the greater the severity of real estate corruption. when there is clear evidence that government officials were involved in the land transfer phase (Land =5), the probability of "quite severe" and "fiercely severe" increases to $0.80(0.32+0.48)$, which is 39 percentage points higher than the reference value of $0.41(0.25+0.16=0.41)$; and when government officials quite often involve in the phase of Plan (Plan $=5)$, the probability of "fiercely severe" $(0.41)$ is higher than the reference value $(0.25)$. Similarly, when government officials enlarge their involvement in the phase of Project, Construction and Sale, the severity scale of real estate corruption all turns higher.

\section{Conclusions and Policy Implications}

\subsection{Conclusions}

Combating corruption is a vital policy goal of governments around the world. To reach this goal, it is essential to get to know the influence factors of corruption better. So far, scholars have primarily paid attention to the macro-level influence factors of corruption, such as state intervention and economic competition. Much less is known about the characteristics of individual officials and how these characteristics affect the size and scale of corruption across China. In this research, we utilize analytical techniques to assess the micro-level factors of individual characteristics such as age and power to shed light on how these characteristics affect corruption. The conclusions are as follows.

Age is not a key factor that affects the severity of real estate corruption. However, as shown in Figure 3, corruption cases most frequently occur for government officials between the ages of 46-50 and 55-60.

The characteristics associated with the inauguration place of government officials do correlate to the severity of real estate corruption. That is, second-tier and third-tier cities are at the risk of high corruption, which implicate transitional process and the rapid urban growth of such Chinese cities may enable corrupt behaviors. Furthermore, government officials in high positions of power within each government level appear to be related to severe corruption; this finding is particularly true for the top leaders of governmental units.

It shows that there has been a lag between corruption being committed and being caught, which have a significant influence on the scale of corruption severity. This indicates that there may be a problem with promoting officials who have participated in corrupt acts in real estate, which in turn greatly increases the occurrence of major cases of real estate corruption.

The corrupt government officials are likely to involve in each phase of real estate development, and obviously, the depth of their involvement acts on the scale of corruption severity. Most of all, the phase of land transfer seems to become a hotbed of corruption.

\subsection{Policy Implications}

The research gives an empirical analysis on the micro-level data collected from the 135 cases, aiming to figure out how the individual characteristics associated with government officials will affect the real estate corruption. Further analysis is needed to derive feasible anti-corruption measures, which has potential to promote better institutions and social cohesion, and ultimately, social sustainability. but anyway, the findings of this study offer some policy recommendations.

First, a more effective anti-corruption policy may not only consider macro determinants of corruption but also take into account the micro determinants such as the power structure, assignment and tenure of government officials. In our findings, inauguration place, position, latent period, and involvement behavior associated with government officials all correlate with real estate corruption. As such, there is need to complement the statutory and institutional reforms with well-packaged and well-focused program to sway the officials away from stepping in corruption. In line with Heineman [55], the best way to handle corruption is forestalling it by prevention means rather than reactive means of rooting it out. 
Second, supervision should increasingly focus its efforts on monitoring officials in charge of departments, officials with oversight authority over key parts of the real estate development process, and governmental heads. These officials are particularly influential in affecting each phase of the real estate development process. Therefore, these officials are able to leverage their power, and the lack of effective governmental oversight to incite bribes [56]. A complete range of supervision activities, such as proactive tightening procedures, judicial examination and punitive discouragement should be carefully probed, together with better protection for whistleblowers' lawful rights and interests. It follows that controlling corruption is not a one-off theme because it requires continuant vigilance and lasting commitment [57].

Third, it is necessary to reform the governance of each phase of real estate development and governmental involvement. The current multi-tier, multi-step approval procedure for real estate development provides numerous opportunities for graft [58,59], especially in the phase of China land transfer, the situation can be viewed as similar to that "applicant must have each of several parts of an application approved; but each approval procedure is independent of the others." [26], which reflects one of the inherent flaws of the fragmented and sequential bureaucracy. Hence, the government should remove unnecessary administrative approvals and reduce unnecessary points of intervention by governmental agencies through structural and institutional reform. By doing so, opportunities for graft could be limited; a more efficient, service-oriented, and transparent government could be formed.

Fourth, the government should increase and enhance audits throughout the tenure of government officials to prevent promoting officials who have participated in corruption. Exposing inappropriate behavior through regular audits may have a chilling effect on current or future corruption, force the audited organizations to reform their management and oversight, and reduce the lag period between when corrupt acts are committed and when they are discovered. The severity scale of real estate corruption increases as leaders rise in rank; this thereby breeds collective corruption, it means that administrative petty corruption walks together with grand political corruption and a vicious circle of systemic corruption will take shape in their interaction [60]. In addition, it is worthwhile to consider applying the 'four-eyes principle' to high-rank officials, which reduces the risk of severe corruption by jointly decision-making by at least two persons [59]. Also, better ethical training should be carried out in different levels of government, especially for officials in high-rank. When appointing and promoting officials, the Chinese government must avoid tolerating mistakes and corruption due to political achievements. By preventing the promotion of corrupt officials to positions of greater power, the government can lower the probability of expanding corruption to different jurisdictions and different levels of government.

There are limitations to this study that point out potential directions for future improvement. First, data used in our research was collected from press releases and media articles rather than from an official comprehensive database; therefore, the scope of the data is confined to information released to the public. A larger dataset could provide greater detail in future analyses. Precisely, the independent variables related to individual characteristics in this study are very limited, for future research it would be better to mention what kinds of individual characteristics for government officials who commit real estate corruption, such as personality, value, work ethic. Additionally, this research only reflects real estate corruption that has been discovered and punished; for every case that is discovered, there may be many more that have not been discovered. The potential presence of unreported or undiscovered crimes not accounted for in official crime statistics could lead to sampling bias. Therefore, a greater number of cases are needed to validate the robustness of the results in this study, and future case studies could include many additional cases that can stand up to rigorous analysis to frame preventive mechanisms and to hold back corruption. If given deeper perceptions into micro-level details for determinant of corruption, additional related doubts could be explained away. For example, it shows that there has been a lag between corruption being committed and being caught; is this because government officials are skillful, or because people just didn't care as much in the past? And, it would be very interesting to see a comparison between the rank of a government official and latency periods. 
Are higher-ranking government officials able to hide cases better? Nevertheless, we believe that our research represents a contribution to understanding the individual determinants of the severity of corruption and suggests organizational measures to improve anti-corruption campaigns. It also represents a suitable starting point and basis for future studies in this field.

Author Contributions: All authors contributed to the conception, research and writing of this manuscript.

Funding: This research was funded by National Social Science Foundation of China (project No. 14BGL106), National Natural Science Foundation of China (project No. 41401631, 41641007, 71774066), Humanity and Social Science Foundation of Ministry of Education of China (project No. 13YJC630115), Thinking Bank Project of Hubei province (project No. HBSXK201616) and, Independent Innovation Fund of Huazhong University of Science and Technology (project No. 2016AC040), Humanity and Social Science foundation of Educational Commission of Hubei Province, China (project No. 17Y014).

Conflicts of Interest: The authors declare no conflict of interest.

\section{References}

1. Mak, S.W.K.; Choy, L.H.T.; Ho, W.K.O. Privatization, housing conditions and affordability in the People's Republic of China. Habitat Int. 2007, 31, 177-192. [CrossRef]

2. Glindro, E.T.; Subhanij, T.; Szeto, J.; Zhu, H. Determinants of house prices in nine Asia-Pacific economies. Int. J. Cent. Bank. 2011, 7, 163-203. [CrossRef]

3. Wang, Y.; Chi, W.; Sun, W. Yingxiang fubai chengdu de quanli he geren yinsu. Jingji Kexue 2008, 164, $105-118$. (In Chinese)

4. Zhang, H. Tudishichangzhong Kaifashang Xinghui Wenti Yanjiu; Huazhong Keji Daxue Chubanshe: Wuhan, China, 2015. (In Chinese)

5. Fan, P. Producing and consuming urban planning exhibition halls in contemporary China. Urban Stud. 2015, 52, 2890-2905. [CrossRef]

6. Cai, H.; Henderson, J.V.; Zhang, Q. China's land market auctions: Evidence of corruption. Rand J. Econ. 2013, 44, 488-521. [CrossRef]

7. Nye, J.S. Corruption and political development: A cost-benefit analysis. Am. Political Sci. Rev. 1967, 61, 417-427. [CrossRef]

8. Park, H.; Blenkinsopp, J. The roles of transparency and trust in the relationship between corruption and citizen satisfaction. Int. Rev. Adm. Sci. 2011, 77, 254-274. [CrossRef]

9. Myrdal, G. Asian Drama: An Inquiry into the Poverty of Nations; Alien Lane; The Penguin Press: London, UK, 1968.

10. Rosenn, K.S. The Jeito Brazil's institutional bypass of the formal legal system and its developmental implications. Am. J. Comp. Law 1971, 19, 514-549. [CrossRef]

11. Tanzi, V. Corruption around the world: Causes, consequences, scope, and cures. Staff Pap. 1998, 45, 559-594. [CrossRef]

12. La Porta, R.; Lopez-de-Silanes, F.; Shleifer, A.; Vishny, R. The quality of government. J. Law Econ. Organ. 1999, 15, 222-279. [CrossRef]

13. Bertrand, M.; Djankov, S.; Hanna, R.; Mullainathan, S. Obtaining a driving license in India: An experimental approach to studying corruption. Q. J. Econ. 2007, 122, 1639-1676. [CrossRef]

14. Dodson, J.; Coiacetto, E.; Ellway, C. Corruption in the Australian land development process: Identifying a research agenda. Governance 2009, 9, 1-25.

15. Murray, C.K.; Frijters, P. Clean money in a dirty system: Relationship networks and land rezoning in Queensland. IZA Discuss. Pap. 2015, 9028, 1-30.

16. Koumpias, A.M.; Martinez-Vazquez, J.; Sanz-Arcega, E. Housing bubbles andzoning corruption: Evidence from Greece and Spain. In Andrew Young School of Policy Studies Research Paper Series (15-11); Georgia State University: Atlanta, GA, USA, 2015.

17. Zhang, F.; Qu, F. Cong difangzhengfu zhijian boyi de jiaodu kan tudishichang zhixu. Jingji Wenti Tansuo 2005, 6, 57-59. (In Chinese)

18. Mu, X. Tudishichangzhong zhengfu yu kaifashang zhijian boyi. Guanli Shijie 2006, 5, 48-49. (In Chinese)

19. Liu, S. Tudizhidu gaige yu guominjingji chengzhang. Guanli Shijie 2007, 9, 1-9. (In Chinese) 
20. Tan, S.; Zhang, Z. Fangdichanlingyu fubai yinsu jiqi zhili duice. Zhongguo Fangdichan 2011, 2, 31-34. (In Chinese)

21. Zhang, H.; Tan, S.; Qi, R. Tudishichangzhong kaifashang xinghui yinsu de jingjixue fenxi. Zhongguo Fangdichan 2011, 12, 17-25. (In Chinese)

22. Zhang, H.; Tan, S. Tudishichangzhong kaifashang xinghui keneng de dingliang panduan. Zhongguo Fangdichan 2012, 8, 64-73. (In Chinese)

23. Zheng, J.; Han, Q. Fangzhi liyi chongtu: Zhili fangdichan fubai de youxiao tujing. Zhongguo Fangdichan 2011, 8,75-80. (In Chinese)

24. Tan, S.; Zhang, Z. Xunzu xingwei zai tudi yongtu guanzhi zhong de yansheng lujing he yizhi: Yi caichanquan wei shijiao de fenxi. Zhongguo Tudi Kexue 2012, 26, 76-81. (In Chinese)

25. Becker, G.S.; Stigler, G.J. Law enforcement, malfeasance, and compensation of enforcers. J. Leg. Stud. 1974, 3, 1-18. [CrossRef]

26. Rose-Ackerman, S. Corruption: A Study of Political Economy; Academic Press: New York, NY, USA, 1978.

27. Treisman, D. The causes of corruption: A cross-national study. J. Public Econ. 2000, 76, 399-457. [CrossRef]

28. De Jong, M.; Henry, W.P.; Stansbury, N. Eliminating corruption in our engineering/construction industry. Leadersh. Manag. Eng. 2009, 9, 105-111. [CrossRef]

29. Aidt, T.S. Economic analysis of corruption: A survey. Econ. J. 2003, 113, 632-652. [CrossRef]

30. Denin, K.I.; Ugol'nitskii, G.A. Game theoretic model of corruption in hierarchic control systems. J. Comput. Syst. Sci. Int. 2010, 49, 152-157. [CrossRef]

31. Le, Y. Jiyu zhuti tezheng de gongcheng fubai guilv shizheng fenxi. Keji Jinbu Yu Duice 2012, 29, 95-99. (In Chinese)

32. Husted, B.W. Wealth, culture, and corruption. J. Int. Bus. Stud. 2008, 30, 339-359. [CrossRef]

33. Getz, K.A.; Volkema, R.J. Culture, perceived corruption, and economics: A model of predictors and outcomes. Bus. Soc. 2001, 40, 7-30. [CrossRef]

34. Davis, J.H.; Ruhe, J.A. Perceptions of country corruption: Antecedents and outcomes. J. Bus. Ethics 2003, 43, 275-288. [CrossRef]

35. Park, H. Determinants of corruption: A cross-national analysis. Multinatl. Bus. Rev. 2003, 11, 29-48. [CrossRef]

36. Ren, J.; Du, Z. Institutionalized corruption: Power overconcentration of the first-in-command in China. Crime Law Soc. Chang. 2008, 49, 45-59.

37. Kotera, G.; Okada, K.; Samreth, S. Government size, democracy, and corruption: An empirical investigation. Econ. Model. 2012, 29, 2340-2348. [CrossRef]

38. Deng, X.; Zhang, L.; Leverentz, A. Official corruption during China's economic transition: Historical patterns, characteristics, and government reactions. J. Contemp. Crim. Justice 2010, 26, 72-88. [CrossRef]

39. Benito, B.; Guillamón, M.D.; Bastida, F. Determinants of urban political corruption in local governments. Crime Law Soc. Chang. 2015, 63, 191-210. [CrossRef]

40. Kim, D.S.; Li, Y.; Tarzia, D. Value of corruption in China: Evidence from anti-corruption investigation. Econ. Lett. 2018, 164, 112-116. [CrossRef]

41. Johnson, S.; Kaufmann, D.; Zoido-Lobaton, P. Regulatory discretion and the unofficial economy. Am. Econ. Rev. 1998, 88, 387-392.

42. Swamy, A.; Knack, S.; Lee, Y.; Azfar, O. Gender and corruption. J. Dev. Econ. 2011, 64, 25-55. [CrossRef]

43. Di Tella, R.; Schargrodsky, E. The role of wages and auditing during a crackdown on corruption in the city of Buenos Aires. J. Law Econ. 2003, 46, 269-292. [CrossRef]

44. Golden, M.A.; Picci, L. Proposal for a new measure of corruption, illustrated with Italian data. Econ. Politics 2005, 17, 37-75. [CrossRef]

45. Mocan, N. What determines corruption? International evidence from micro-data. Econ. Inq. 2008, 46, 493-510. [CrossRef]

46. Olken, B.A.; Barron, P. The simple economics of extortion: Evidence from trucking in Aceh. J. Political Econ. 2009, 117, 417-452. [CrossRef]

47. Dong, B.; Dulleck, U.; Torgler, B. Conditional corruption. J. Econ. Psychol. 2012, 33, 609-627. [CrossRef]

48. Bourgon, J. Responsive, responsible, and respected government: Towards a new public administration theory. Int. Rev. Adm. Sci. 2007, 73, 7-26. [CrossRef]

49. Torgler, B.; Valev, N.T. Corruption and age. J. Bioecon. 2006, 8, 133-145. [CrossRef] 
50. Duncan, C.S.; Khattak, A.J.; Council, F.M. Applying the ordered probit model to injury severity in truck-passenger car rear-end collisions. Transp. Res. Rec. 1995, 1635, 63-71. [CrossRef]

51. Ye, F.; Lord, D. Comparing three commonly used crash severity models on sample size requirements: Multinomial logit, ordered probit and mixed logit models. Anal. Methods Accid. Res. 2014, 1, $72-85$. [CrossRef]

52. Greene. Econometric Analysis; Prentice-Hall Press: New York, NY, USA, 2012.

53. Long, J.S. Regression Models for Categorical and Limited Dependent Variables; Sage Publications: London, UK, 1997.

54. Washington, S.P.; Karlafatis, M.G.; Mannering, F.L. Statistical and Econometric Methods for Transportation Data Analysis. requirements: Multinomial logit, ordered probit and mixed logit models. Anal. Methods Accid. Res. 2003, 1, 72-85.

55. Heineman, B.W.; Heinemen, F. The long war against corruption. Foreign Aff. 2006, 85, 75-86. [CrossRef]

56. Graycar, A.; Sidebottom, A. Corruption and control: A corruption reduction approach. J. Financ. Crime 2012, 19, 384-399. [CrossRef]

57. Dininio, P.; Kpundeh, S.J.; Leiken, R. USAID Handbook for Fighting Corruption Center for Democracy and Governance; US Agency for International Development: Washington, DC, USA, 1998.

58. Shleifer, A.; Vishny, R.W. Corruption. Q. J. Econ. 1993, 108, 599-617. [CrossRef]

59. Sun, G.; Lu, M.; Zhang, J.P. Anti-corruption, market construction and economic growth. China Econ. Q. 2005, 4, 1-22.

60. Budak, J.; Rajh, E. Corruption Survey in Croatia: Survey Confidentiality and Trust in Institutions; Working Papers; EIZ: Zagreb, Croatia, 2012.

(C) 2019 by the authors. Licensee MDPI, Basel, Switzerland. This article is an open access article distributed under the terms and conditions of the Creative Commons Attribution (CC BY) license (http://creativecommons.org/licenses/by/4.0/). 